\title{
DESAIN PERANGKAT PEMBELAJARAN KIMIA POKOK MATERI TITRASI ASAM BASA DENGAN MODEL PEMBELAJARAN INKUIRI YANG DIINTEGRASIKAN DENGAN STRATEGI PETA KONSEP UNTUK MENINGKATKAN HASIL BELAJAR SISWA
}

\author{
Khasanah $^{1)}$, Mohamad Nur ${ }^{2)}$, Suyatno ${ }^{3)}$ \\ ${ }^{1)}$ Mahasiswa Program Studi Pendidikan Sains, Program Pascasarjana Universitas Negeri Surabaya \\ ${ }^{2), 3)}$ Dosen Pascasarjana Prodi Pendidikan Sains Univesrtitas Negeri Surabaya \\ E-mail: kasanahkasanah75@gmail.com
}

\begin{abstract}
Abstrak: Penelitian ini bertujuan untuk mendeskripsikan kevalidan, kepraktisan, dan keefektifan perangkat pembelajaran model pembelajaran inkuiri yang diintegrasikan dengan strategi peta konsep dalam upaya untuk meningkatkan hasil belajar aspek pengetahuan, dan aspek keterampilan proses sains siswa SMAN 1 Sangatta Utara pada materi pokok titrasi asam basa. Jenis penelitian ini merupakan penelitian desain perangkat pembelajaran. Perangkat pembelajaran yang didesainkan, meliputi: RPP, LKS, BAS, danTHB, dengan menggunakan model desain perangkat Dick \& Carey serta rancangan uji coba perangkat yang digunakan adalah One Group Pre-test and Post-test Design. Teknik analisis yang dikembangkan adalah deskriptif kuantitatif dan deskriptif kualitatif. Hasil penelitian menunjukkan bahwa (1) validasi RPP berkategori sangat baik, validasi LKS dan BAS berkategori baik, serta validasi soal tes berkategori valid, keterbacaan BAS 82\% merespon positif dan keterbacaan LKS 76\% merespon positif (2) Keterlaksanaan RPP berkategori sangat baik, aktivitas siswa berkategori sangat baik, kendala-kendala yang dialami pada saat penelitian, meliputi: pelaksanaan KBM memerlukan waktu yang lama, ada siswa yang memecahkan alat, dan kurang aktif dalam praktek pada pertemuan ke dua (3) respon siswa terhadap pembelajaran berkategori sangat baik, ketuntasan aspek pengetahuan $89,47 \%$ dan ketuntasan aspek keterampilan proses sains $86,84 \%$. Siswa mengalami peningkatan hasil belajar aspek pengetahuan $84,21 \%$ berkategori tinggi, dan $15,79 \%$ berkategori sedang, sedangkan untuk aspek keterampilan proses sains $42,11 \%$ berkategori tinggi dan $57,89 \%$ berkategori sedang. Berdasarkan temuan hasil penelitian dapat disimpulkan bahwa perangkat pembelajaran kimia materi pokok titrasi asam basa menggunakan model pembelajaran inkuiri yang diintegrasikan dengan strategi peta konsep layak dan dapat digunakan dalam pembelajaran untuk meningkatkan hasil belajar siswa.
\end{abstract}

Kata Kunci: Perangkat Pembelajaran, Titrasi Asam Basa, Model Pembelajaran Inkuiri, Strategi Peta Konsep, Hasil Belajar.

Abstract: This study aimes to describe the validity, practicality and effectiveness of the device learning inquiry models that are integrated with the concept maps strategy in an effort to improve aspects of knowledge and science process skills of students SMAN 1 North Sangatta on titration acid base topic. Learning materials developed include: lesson plans, student worksheet, student book, and achievement test. This design research is developmented research using Dick \& Carey with the tryout of the teaching materials used one group pre test and post test design. The analysis technique used is descriptive quantitative and qualitative descriptive. the results showed that (1) validation leson plans quite well category, student worksheet, and student book good enough category, item test is generally valid, and legibility of student book $76 \%$ responded positively legibility, student worksheet $82 \%$ responded positively (2) lesson plans category quite well, student activities categorized well, and constraints experienced during the study include: the implementation of the Teaching and learning Activities require a long time, there are students who break the tool and less active at the meeting to two, (3) student response categorized excellent learning, mastery of the knowledge aspect of $89.47 \%$, completeness aspect of science process skills $86.84 \%$. Students experiencing learning outcome aspects of knowledge $84,21 \%$ higher category. Based on the result of the development of chemistry learning package main material acid base titration using the inquiry model integrated with concept maps strategy produced was feasible so it can be used in learning to improve student learning outcomes.

Keywords : Learning Package, Acid-Base Titration, Inquiry Model, Strategy Concept Maps, and Learning Outcomes.

\section{PENDAHULUAN}

Pendidikan Nasional abad XXI bertujuan untuk mewujudkan cita-cita bangsa, yaitu masyarakat Indonesia yang sejahtera, bahagia, dengan kedudukan yang terhormat dan setara dengan bangsa lain dalam dunia global, melalui pembentukan masyarakat yang terdiri dari sumber daya manusia yang berkualitas, yaitu pribadi yang mandiri, berkemauan dan berkemampuan untuk mewujudkan cita-cita bangsanya (BNSP, 2010). Tujuan pendidikan tersebut tidak akan terwujud tanpa 
adanya peran serta dari seluruh mayarakat Indonesia. Saat ini masih banyak permasalahan yang terjadi dalam dunia pendidikan bangsa Indonesia. Salah satu permasalahan pendidikan yang dihadapi bangsa Indonesia saat ini adalah rendahnya mutu pendidikan pada setiap jenjang dan satuan pendidikan, khususnya pada pendidikan dasar dan menengah. Berbagai upaya telah dilakukan untuk meningkatkan mutu pendidikan nasional.

Namun demikian berbagai indikator pendidikan belum menunjukkan peningkatan yang merata. Sebagian sekolah, terutama di kota-kota, menunjukkan peningkatan mutu pendidikan yang cukup menggembirakan, namun sebagian yang lainnya masih memprihatinkan (Poerwati, 2013). Kendala lain yang dihadapi bangsa Indonesia dalam dunia pendidikan adalah mengalami kemerosotan pendidikan diakibatkan oleh hilangnya karakter bangsa Indonesia (Muin, 2011). Salah satu upaya pemerintah untuk meningkatkan mutu pendidikan di Indonesia adalah dengan memperbaiki sistem kurikulum (Rahayu, dkk., 2013). Sangatlah wajar, jika pemerintah memunculkan Kurikulum 2013 yang menitik beratkan pada pendidikan karakter bangsa dan pendekatan saintifik.

Banyak guru yang menerapkan model pembelajaran konvensional berakibat nilai sains siswa menurun. Hal ini berdasarkan survai TIMSS tahun 2011 menempatkan siswa Indonesia berada di posisi skala rata-rata 402 untuk domain kognitif knowing (turun 23 skala dibandingkan tahun 2007), 398 untuk applying (turun 24 skala), dan 413 untuk reasoning (turun 17 skala). Sementara itu berdasarkan laporan yang dikeluarkan oleh Programme for International Student Assesment (PISA) tahun 2009 yang dinyatakan bahwa sekitar $65 \%$ peserta dari Indonesia tidak mencapai level 2 dalam kemampuan sains. Tingkatan tersebut mensyaratkan penggunaan pengetahuan sains yang memadai untuk memberikan penjelasan yang masuk akal dalam konteks yang familiar atau menarik kesimpulan berdasarkan penyelidikan sederhana (Fleischman, 2010).

Sidi (2000) berpendapat bahwa banyak permasalahan ditemukan dalam pendidikan kimia di lapangan, seperti rendahnya nilai kimia baik pada ulangan harian, ulangan umum, rapor, maupun NEM. Hal ini menunjukkan betapa sulitnya materi kimia dipelajari siswa. Beberapa faktor yang diduga menjadi penyebab semua itu adalah kemampuan awal siswa, kompetensi guru, bahan ajar, serta sarana prasarana pendukungnya.

Lynch (1980), Nakhleh (1992) menyatakan bahwa beberapa hal yang diduga menyebabkan kurangnya penguasaan konsep materi pelajaran kimia, yaitu (1) siswa sering belajar dengan cara menghafal tanpa membentuk pengertian terhadap materi yang dipelajari, (2) materi pelajaran yang diajarkan memiliki konsep mengambang, sehingga siswa tidak dapat menemukan kunci untuk mengerti materi yang dipelajari, (3) tenaga pengajar (guru) mungkin kurang berhasil dalam menyampaikan kunci terhadap penguasaan konsep materi pelajaran yang sedang diajarkan. Berbagai paradigma permasalahan dalam pembelajaran kimia ini harus dapat dipecahkan oleh pendidik yang notaben adalah guru kimia, maka dari itu sudah selayaknya guru harus membuat suatu inovasi pembelajaran yang dapat membantu meningkatkan mutu pendidikan,

Llewellyn (2005) dalam NRC (1996) yang menyatakan bahwa inkuiri adalah suatu kegiatan yang melibatkan banyak hal dalam melakukan pengamatan, yakni: mengajukan pertanyaan, memeriksa sumber buku dan sumber informasi lain sebagai sumber landasan untuk membuktikan hasil percobaan, menggunakan alat dan bahan percobaan untuk mengumpulkan, menganalisis, dan menginterpretasi data, mengajukan jawaban, penjelasan dan prediksi dan mengkomunikasikan hasil. Inkuiri memerlukan identifikasi asumsi, penggunaan pemikiran kritis dan logis dan pertimbangan akan penjelasan-penjelasan alternatif.

Model pembelajaran inkuiri merupakan salah satu model pembelajaran yang diterapkan dalam Kurikulum 2013 untuk pembelajaran sains di sekolah menengah khususnya SMA program IPA. Penerapan pembelajaran dengan model inkuri tidaklah mudah, melainkan melalui suatu kendala. Adapun salah satu kendala yang terjadi dalam menerapkan model pembelajaran inkuiri ini adalah lamanya waktu yang digunakan dalam proses pembelajaran. Hal ini sesuai dengan pernyataan Ariadi (2010) bahwa model pembelajaran inkuiri memerlukan jumlah jam pelajaran kelas yang banyak dan juga waktu di luar kelas.

Pelaksanaan pembelajaran menggunakan model inkuiri dengan waktu yang relatif singkat dapat menyebabkan konsep pengetahuan yang diterima siswa kurang maksimal, untuk mengatasi kendala ini maka model inkuiri perlu diintegrasikan dengan strategi pembelajaran lain. Salah satu upaya untuk memantapkan konsep yang telah diperoleh siswa dalam model pembelajaran inkuiri adalah dengan mengintegrasikan dengan strategi peta konsep.

Dahar (1988) menyatakan 4 manfaat yang diperoleh siswa jika belajar dengan strategi peta konsep, yaitu: (1) strategi peta konsep dapat digunakan untuk menyelidiki konsep yang telah dimiliki siswa agar dalam proses belajar yang akan dipelajarinya lebih bermakna, (2) peta konsep berfungsi untuk menolong siswa dalam memahami pelajaran dalam suatu bab materi yang dipelajari, (3) peta konsep dapat 
mengungkapkan konsep yang salah terjadi pada siswa, (4) peta konsep dapat digunakan sebagai alat evaluasi.

Hasil penelitian Wahyudi (2013) menunjukkan bahwa hasil belajar fisika siswa yang belajar menggunakan inkuiri terbimbing yang dipadu dengan peta konsep lebih tinggi daripada hasil belajar siswa yang belajar menggunakan pembelajaran inkuiri terbimbing saja, sedangkan hasil penelitian Adi, dkk. (2012) menjelaskan bahwa kelompok siswa yang belajar mengikuti model pembelajaran inkuiri terbimbing berbantuan teknik peta konsep menunjukkan pemahaman konsep yang lebih baik dibandingkan dengan siswa yang belajar mengikuti model pembelajaran konvensional pada siswa kelas $\mathrm{V}$ SD Kaliasem terhadap pemahaman konsep IPA. Sementara itu penelitian Saptorini (2008) menunjukkan bahwa guru yang memiliki pemahaman tentang model inkuiri yang rendah berdampak pada kemampuan siswa di dalam membuat peta konsep juga rendah. Berdasarkan penelitian di atas menunjukkan bahwa pembelajaran inkuiri terbimbing yang diintegrasikan dengan strategi peta konsep memiliki pengaruh positif terhadap hasil belajar siswa.

Berdasarkan analisis hasil angket siswa kelas XII SMAN 1 Sangatta Utara tahun ajaran 2014/2015 dan hasil pengalaman mengajar peneliti menunjukkan bahwa materi pokok titrasi asam basa dianggap sulit.walaupun metode eksperimen telah digunakan. Pembenahan pada pembuatan perangkat pembelajaran, pelaksanaan pembelajaran dan evaluasi mutlak dilakukan peneliti untuk membantu kesulitan siswa ini. Nieveen (1999) berpendapat ada 3 cara yang dapat ditempuh oleh guru kimia untuk memperbaiki kelayakan suatu perangkat pembelajaran yang akan digunakan dalam PBM di sekolah, yaitu mencakup kevalidan perangkat pembelajaran, kepraktisan perangkat pembelajaran, dan keefektifan perangkat pembelajaran. Berdasarkan latar belakang kesulitan belajar siswa pada materi pokok titrasi asam basa dan beberapa hasil temuan penelitian oleh para peneliti sebelumnya serta teori di atas maka peneliti tertarik untuk melakukan penelitian tentang inovasi pendidikan dalam pembelajaran kimia, yaitu dengan mengembangkan suatu perangkat pembelajaran kimia dengan judul penelitian "Desain perangkat pembelajaran kimia pada materi pokok titrasi asam basa dengan menggunakan model pembelajaran inkuiri yang diintegrasikan dengan strategi peta konsep untuk meningkatkan hasil belajar siswa."

\section{METODE PENELITIAN}

Jenis penelitian ini adalah penelitian desain perangkat pembelajaran kimia materi pokok titrasi asam basa menggunakan model inkuiri yang diintegrasikan dengan strategi peta konsep. Perangkat pembelajaran didesain menggunakan model Dick \& Carey. Perangkat yang didesain meliputi: Rencana Pelaksaan Pembelajaran (RPP), Lembar Kegiatan Siswa (LKS), Buku Ajar Siswa (BAS), dan Lembar Penilaian (LP).

Emzir (2007), dengan cara membandingkan hasil belajar sebelum memperoleh pengalaman belajar menggunakan model inkuiri yang diintegrasikan dengan strategi peta konsep dengan hasil belajar setelah memperoleh pengalaman belajar menggunakan model inkuiri yang diintegrasikan dengan strategi peta konsep. Penelitian ini tanpa kelompok pembanding (kontrol). Rumusan rancangan uji coba 2 sebagai berikut:

$$
\begin{array}{lll}
\mathbf{O}_{1} & \mathbf{X} & \mathbf{O}_{2}
\end{array}
$$

Keterangan:

$\mathrm{O}_{1}=$ Pengujian awal untuk mengetahui penguasaan materi sebelum pemberian perlakuan dengan menggunakan perangkat pembelajaran model inkuiri yang diintegrasikan dengan strategi peta konsep.

$\mathrm{X}=$ Pemberian perlakuan dengan menggunakan perangkat pembelajaran model inkuiri yang diintegrasikan dengan strategi peta konsep.

$\mathrm{O}_{2}=$ Pengujian akhir untuk mengetahui penguasaan materi setelah pemberian perlakuan dengan menggunakan perangkat pembelajaran model inkuiri yang diintegrasikan dengan strategi peta konsep.

Populasi dalam penelitian ini adalah siswa kelas XI MIA-3 SMAN 1 Sangatta Utara pada semester 1 tahun ajaran 2014/2015 terdiri dari 38 orang.

Penelitian ini merupakan penelitian desain karena mendesainkan perangkat pembelajaran yang terdiri dari Rencana Pelaksanaan Pembelajaran (RPP), Buku Ajar Siswa (BAS), Lembar Kerja Siswa (LKS), dan Tes Hasil Belajar (THB). Penelitian desaisn ini mengacu pada model desain Dick \& Carey. Model pengembangan tersebut terdiri atas: (1) identifikasi tujuan, (2) melakukan analisis intruksional, (3) menganalisis warga belajar dan lingkungan, (4) merumuskan tujuan khusus, (5) mengembangkan instrumen penilaian, (6) mengembangkan strategi pembelajaran, (7) mengembangkan materi pelajaran, (8) merancang dan mengembangkan formatif, (9) mengembangkan evaluasi sumatif dan (10) merevisi. Perangkat pembelajaran dengan model pembelajaran inkuiri terbimbing yang diintegrasikan dengan strategi peta konsep yang telah didesain selanjutnya diuji cobakan dalam kegiatan pembelajaran kimia di kelas XI SMA program kimia pada pokok bahasan titrasi asam basa.

Tahap pelaksanaan, penerapan perangkat pembelajaran yang sudah divalidasa oleh 4 validator kemudian diujicobakan pada populasi yang terdiri dari 
38 orang siswa. Pada tahap ini peneliti bertindak sebagai pengajar dan siswa sebagai kelompok yang akan diteliti. Pelaksanaan penelitian dimulai dengan mengadakan tes awal (pretest), kegiatan pembelajaran yang menerapkan model inkuiri terbimbing yang diintegrasikan dengan strategi peta konsep, dan uji akhir (posttest). Selama pembelajaran berlangsung dilakukan juga observasi terhadap kemampuan guru dalam mengelola KBM dan aktivitas siswa selama mengikuti kegiatan pembelajaran, serta hambatanhambatan yang ditemui selama kegiatan pembelajaran. Selanjutnya diakhir pembelajaran siswa diberikan angket respon siswa untuk mengetahui minat siswa terhadap kegiatan pembelajaran. Penelitian pelaksanaan pembelajaran di kelas digunakan sebagai validasi empirik untuk mencari data respon, reaksi atau komentar siswa dan pengamat. Hasil penelitian ini dianalisis, kemudian digunakan untuk penyusunan laporan akhir sehingga menghasilkan naskah perangkat ajar yang siap diimplementasikan.

Penerapan perangkat pembelajaran di kelas dilaksanakan sesuai jadwal yang telah disusun oleh wakil kepala sekolah bidang kurikulum dengan alokasi waktu 4 kali pertemuan (4 jam tatap muka). Instrumen yang digunakan dalam penelitian adalah alat bantu yang digunakan untuk mengumpulkan data yang diperoleh dari proses penelitian. Diantaranya adalah:

1. Lembar Validasi, digunakan untuk mendeskripsikan validitas perangkat pembelajaran yang dikembangkan.

2. Lembar Pengamatan Keterlaksanaan RPP, digunakan untuk mendeskripsikan keterlaksanaan dalam penggunaan perangkat pembelajaran yang dikembangkan sesuai urutan sitaks yang tertuang pada RPP.

3. Lembar Pengamatan Aktivitas Siswa, digunakan untuk merekam aktivitas siswa selama proses pembelajaran.

4. Lembar Pengamatan Kendala selama KBM, digunakan untuk mengamati hambatan-hambatan yang ditemui oleh guru selama proses pembelajaran.

5. Lembar Angket Respon Siswa, digunakan untuk mendapatkan informasi terhadap efektifitas, validitas, dan keterbacaan perangkat pembelajaran dan model pembelajaran.

6. Tes Aspek Pengetahuan, digunakan untuk mengukur penguasaan konsep siswa sebelum dan setelah pembelajaran

7. Tes Aspek Keterampilan Proses Sains, digunakan untuk mengukur penguasaan konsep siswa sebelum dan setelah pembelajaran yang meliputi merumuskan masalah, merumuskan hipotesis, mengidentifikasi variabel dan membuat definisi operasional variabel, merancang prosedur untuk melakukan percobaan, mengorganisasi data, menganalisis data dan menarik kesimpulan.

Teknik yang digunakan untuk mengumpulkan data adalah melalui observasi, pemberian tes, dan pemberian angket. Analisis data dilakukan dengan menggunakan teknik deskriptif kuantitatif dan deskriptif kualitatif.

\section{HASIL PENELITIAN DAN PEMBAHASAN}

\section{A. Hasil Pengembangan Perangkat Pembelajaran}

Pengembangan perangkat pembelajaran sangat diperlukan dalam rangka menunjang keterlaksanaan proses pembelajaran. Perangkat yang diterapkan dalam penelitian ini meliputi Rencana Pelaksanaan Pembelajaran (RPP), Buku Ajar Siswa, Lembar Kerja Siswa (LKS) dan Tes Aspek Pengetahuan, dan Tes Aspek Keterampilan Proses sains. Perangkat pembelajaran yang telah selesai dibuat selanjutnya dikonsultasikan dengan validator untuk menguji validitasnya. Validasi perangkat dilakukan oleh 4 orang validator ( 3 validator tetap dan 1 validator pengganti) dengan tujuan untuk memperoleh masukan dan catatan atas perangkat yang telah dibuat agar layak untuk diterapkan pada penelitian. Hasil analisis skor rata-rata dikategorikan pada Tabel 1 sebagai berikut :

Tabel 1. Kriteria Pengkategorian Perangkat Pembelajaran

\begin{tabular}{|c|c|l|}
\hline $\begin{array}{c}\text { Interval } \\
\text { Skor }\end{array}$ & $\begin{array}{c}\text { Kategori } \\
\text { Penilaian }\end{array}$ & \multicolumn{1}{|c|}{ Keterangan } \\
\hline $\begin{array}{c}1,00 \\
\mathrm{SV} \leq 1,69\end{array}$ & $\begin{array}{c}\text { Tidak } \\
\text { baik }\end{array}$ & $\begin{array}{l}\text { Tidak layak, belum dapat } \\
\text { digunakan dan masih } \\
\text { memerlukan konsultasi }\end{array}$ \\
\hline $\begin{array}{c}1,70 \\
\leq \mathrm{SV} \leq 2,59\end{array}$ & $\begin{array}{c}\text { Kurang } \\
\text { baik }\end{array}$ & $\begin{array}{l}\text { Kurang layak, dapat } \\
\text { digunakan dengan revisi } \\
\text { lebih besar }\end{array}$ \\
\hline $\begin{array}{c}2,60 \\
\leq \mathrm{SV} \leq 3,59\end{array}$ & baik & $\begin{array}{l}\text { Layak, dapat digunakan } \\
\text { dengan revisi kecil }\end{array}$ \\
\hline $\begin{array}{c}3,60 \\
\leq \mathrm{SV} \leq 4,00\end{array}$ & $\begin{array}{c}\text { Sangat } \\
\text { baik }\end{array}$ & $\begin{array}{l}\text { Layak, dapat digunakan } \\
\text { tanpa revisi }\end{array}$ \\
\hline
\end{tabular}

(Diadopsi dari BNSP, 2006)

Hasil penilaian perangkat oleh validator secara umum dapat dilihat pada Gambar 1.

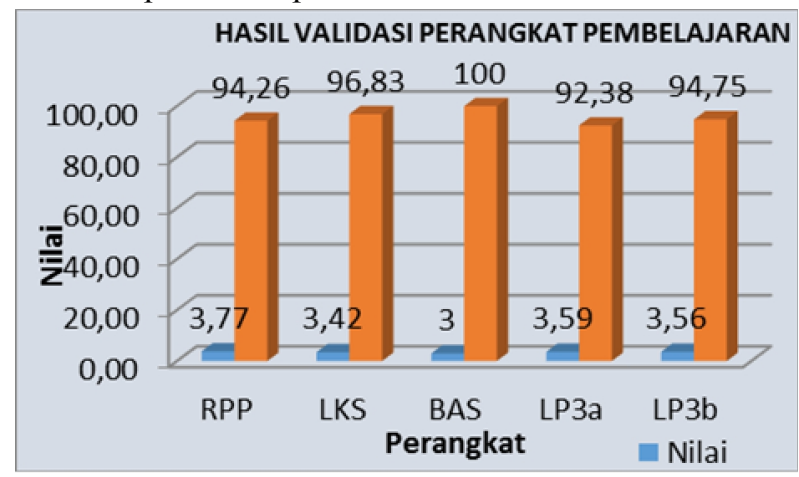

Gambar 1. Hasil Validasi dan Realibilitas Perangkat 


\section{Keterangan :}

RPP: Rencana Pelaksanaan Pembelajaran

LKS: Lembar Kegiatan Siswa

BAS: Buku Ajar Siswa

LP 3a: Tes Aspek Pengetahuan

LP 3b: Tes Aspek Keterampilan Proses Sains

Berdasarkan Gambar 1 di atas dapat disimpulkan bahwa hasil penilaian validator terhadap perangkat yang sudah dibuat adalah valid dan layak untuk digunakan dengan sedikit revisi sesuai saran validator.

\section{B. Tahap penerapan perangkat pembelajaran \\ 1. Keterlaksanaan RPP}

Keterlaksanaan penggunaan perangkat pembelajaran dilakukan oleh dua orang pengamat. Pada penelitian ini dibuat 4 kali pertemuan selama 90 menit setiap satu kali pertemuan. Pertemuan 1 berkaitan dengan memberikan latihan pada siswa tentang model pembelajaran inkuiri dan cara membuat peta konsep dengan model pembelajaran langsung (MPL), sedangkan pada pertemuan kedua sampai keempat siswa diajar dengan model pembelajaran inkuiri yang diintegrasikan dengan strategi peta konsep untuk melakukan percobaan titrasi asam kuat basa kuat, asam lemah basa kuat, dan basa lemah dengan asam kuat. Hasil pengamatan terhadap keterlaksanaan pembelajaran kimia materi titrasi asam basa dengan model pembelajaran inkuiri yang diintegrasikan dengan strategi peta konsep yang dilakukan oleh dua orang pengamat menggunakan lembar Keterlaksanaan RPP dihitung reliabilitasnya, dan disajikan secara ringkas pada Tabel 2. berikut.

Tabel 2. Reliabilitas Lembar Keterlaksanaan RPP

\begin{tabular}{|l|l|l|l|l|l|}
\hline $\begin{array}{l}\text { Pengamatan } \\
\text { terhadap }\end{array}$ & \multicolumn{4}{|l|}{$\begin{array}{l}\text { Reliabilitas RPP Tiap } \\
\text { Pertemuan (\%) }\end{array}$} & Rata-rata \\
\hline Guru & 96 & 95.4 & 93.8 & 99.4 & 96.15 \\
\hline
\end{tabular}

Tabel 2. menunjukkan bahwa reliabilitas instrumen pembelajaran masing-masing RPP melebihi 75\%, dengan rata-rata sebesar $96.15 \%$. Keterlaksanaan RPP juga dinyatakan dengan persentase keterlaksanaan dan kualitas nilai keterlaksanaan disajikan pada Gambar 2

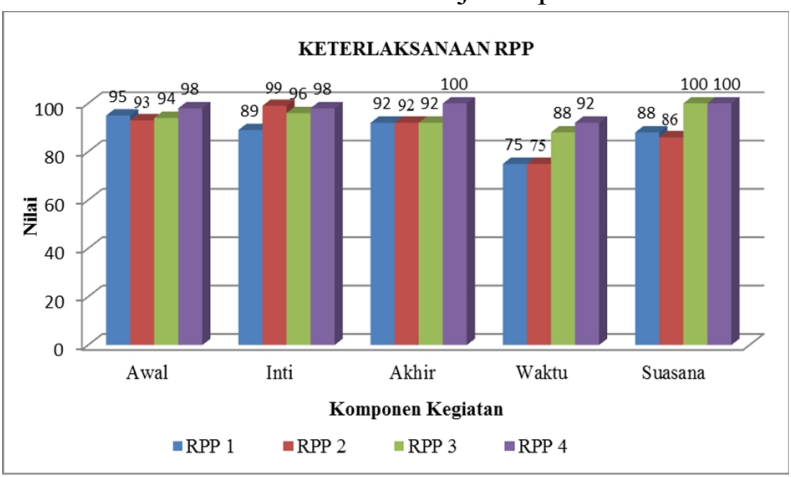

Gambar 2. Diagram keterlaksanaan RPP
Berdasarkan Gambar 2 tentang keterlaksanaan RPP menunjukkan bahwa kemampuan guru dalam melaksanakan kegiatan pembelajaran model pembelajaran inkuiri yang diintegrasikan dengan strategi peta konsep berlangsung dengan baik dibuktikan dengan peningkatan tiap pertemuan.

Peningkatan skor keterlaksanaan RPP juga terjadi karena proses belajar diupayakan semaksimal mungkin sesuai dengan Sintaks yang telah dikembangkan, dan disajikan secara ringkas pada Tabel 3 berikut

Tabel 3. Sintaks model pembelajaran inkuiri yang diintegrasikan dengan strategi peta konsep

\begin{tabular}{|c|c|}
\hline Tahap & Kegiatan \\
\hline $\begin{array}{l}\text { Fase } 1 \\
\text { identifikasi dan } \\
\text { penetapan ruang } \\
\text { lingkup masalah } \\
\text { Membuat peta } \\
\text { konsep awal }\end{array}$ & 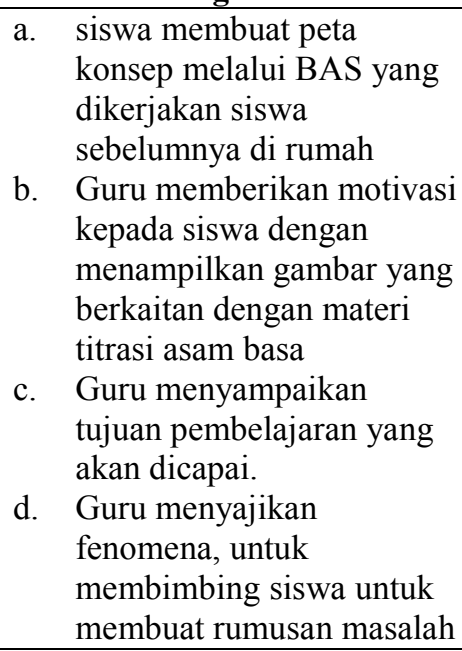 \\
\hline $\begin{array}{l}\text { Fase } 2 \\
\text { perumusan } \\
\text { hipotesis }\end{array}$ & $\begin{array}{l}\text { a. Guru membimbing siswa } \\
\text { untuk mengajukan hipotesis } \\
\text { dan menuangkan hipotesis }\end{array}$ \\
\hline $\begin{array}{l}\text { Fase } 3 \\
\text { Mengumpulkan } \\
\text { data percobaan }\end{array}$ & $\begin{array}{l}\text { a. Guru membimbing siswa } \\
\text { mengidentifikasi variabel. } \\
\text { b. Guru membimbing siswa } \\
\text { membuat definisi } \\
\text { operasioanl variabel. } \\
\text { c. Guru membimbing siswa } \\
\text { menentukan alat bahan } \\
\text { d. Guru membimbing siswa } \\
\text { membuat prosedur } \\
\text { percobaan. } \\
\text { e. Guru membimbing siswa } \\
\text { melakukan percobaan. }\end{array}$ \\
\hline $\begin{array}{l}\text { Fase } 4 \\
\text { Mengorganisasi } \\
\text { data }\end{array}$ & $\begin{array}{l}\text { a. Guru membimbing siswa } \\
\text { membuat Tabel } 1 \text { dan Tabel } \\
2 . \\
\text { b. Guru membimbing siswa } \\
\text { memasukkan data percobaan } \\
\text { ke dalam Tabel } 1 \text { dan Tabel } \\
2 . \\
\text { c. Guru membimbing siswa } \\
\text { membuat kurva titrasi asam } \\
\text { basa. }\end{array}$ \\
\hline $\begin{array}{l}\text { Fase } 5 \\
\text { Interpretasi data }\end{array}$ & $\begin{array}{l}\text { a. Guru membimbing siswa } \\
\text { menjawab pertanyaan pada } \\
\text { analisis data dalam LKS. } \\
\text { b. Siswa membuat peta konsep } \\
\text { tentang materi yang telah } \\
\text { dipelajari berdasarkan }\end{array}$ \\
\hline
\end{tabular}




\begin{tabular}{|l|l|}
\hline \multicolumn{1}{|c|}{ Tahap } & \multicolumn{1}{c|}{ Kegiatan } \\
\hline & $\begin{array}{l}\text { wacana yang ada dalam LKS. } \\
\text { cecara bergiliran siswa } \\
\text { mempresentasikan hasil } \\
\text { jawaban pada analisis data di } \\
\text { depan kelas }\end{array}$ \\
\hline $\begin{array}{l}\text { Fase 6 } \\
\text { Pengembangan } \\
\text { kesimpulan }\end{array}$ & $\begin{array}{l}\text { Guru membimbing siswa untuk } \\
\text { membuat kesimpulan akhir } \\
\text { materi berdasarkan hasil } \\
\text { analisis data dari setiap } \\
\text { pertemuan }\end{array}$ \\
\hline
\end{tabular}

(Diadaptasi dari Joyce dan Weil, 2009)

Pemberian motivasi pada tahapan identifikasi dan penetapan ruang lingkup masalah, dilakukan siswa pada saat membuat rumusan masalah dapat meningkatkan minat belajar siswa. Hal ini menurut teori pemrosesan informasi akan mempengaruhi penyimpanan informasi yang dipelajari ke memori jangka panjang sehingga meningkatkan penguasaan konsep (Slavin, 2011). Tahap perumusan hipotesis pada saat siswa membuat rumusan hipotesis dapat meningkatkan penguasaan konsep karena pada tahapan ini siswa diajari untuk menyimpan informasi ke memori jangka panjang (Savin, 2011).

Tahap pengumpulan data melalui percobaan kelompok memberi kesempatan kepada siswa untuk terlibat aktif menemukan sendiri konsep yang dipelajari melalui aktivitas fisik dan mental. Tahapan ini siswa melakukan kegiatan, meliputi: menentukan variabel dan definisi operasional variabel, menentukan alat bahan, dan prosedur kerjanya, melakukan percobaan titrasi asam basa di laboratorium. Secara langsung siswa telah melakukan kegiatan keterampilan proses sains sebagai pendukung dalam penemuan sains. Pendapat ini diperkuat oleh Bruner yang menyatakan bahwa partisipasi siswa yang aktif dalam penguasaan konsepkonsep dan prinsip-prinsip akan mempermudah siswa di dalam memperoleh pengalaman dan melakukan eksperimen untuk membuktikan kebenaran prinsipprinsip. Dewey berpendapat bahwa guru dapat melibatkan siswa dalam proyek-proyek yang berorientasi masalah dan membantu mereka dalam menyelidiki masalah-masalah sosial dan IPTEK (Nur, 2011). Kedua kegiatan tersebut menurut Piaget menyebabkan proses akomodasi konsep yang dilakukan siswa semakin baik sehingga mudah diasimilasi ke dalam struktur konsep (skemata) di otak (Dahar, 1998). Dasar teori ini mengisyaratkan bahwa penguasaan konsep yang dicapai siswa semakin meningkat.

Tahap interpretasi data dan tahap pengembangan kesimpulan, saat siswa melakukan pengukuran $\mathrm{pH}$ larutan campuran analit, melakukan pengukuran volume larutan standar, melakukan pencatatan data pada tabel, analisis data percobaan, dan membuat kesimpulan dari percobaan akan menambah keterampilan proses sains siswa semakin bertambah karena akan terjadi diskusi antar siswa karena dapat meningkatkan daya akomodasi dan asimilasi konsep. Sementara itu interaksi sosial, terutama dengan teman sebayanya yang lebih pandai serta bimbingan guru, menurut Vygotsky akan mampu memperbesar tingkat perkembanagn potensial siswa sehingga meningkatkan ZPD (Slavin, 2011), dengan meningkatnya ZPD tersebut maka siswa akan semakin mudah menguasai konsep yang sedang dipelajari.

Pembuatan peta konsep di awal pembelajaran, akan membantu guru untuk mengarahkan siswa ke materi yang akan dipelajari, dan menolong siswa untuk mengingat kembali informasi yang berhubungan yang dapat digunakan untuk membantu menanamkan pengetahuan baru yang bertindak sebagai pertolongan mental sebelum materi baru disajikan. Pembuatan peta konsep pada wacana di analisis data membantu siswa untuk menghilangkan miskonsepsi yang siswa alami sebelumnya sehingga informasi yang baru dapat digunakan sebagai tindak perbaikan atas kesalahan konsep yang dialami siswa saat sebelum menerima pengetahuan baru.

\section{Aktivitas Siswa}

Aktivitas siswa selama pembelajaran diamati oleh dua orang pengamat menggunakan lembar pengamatan aktivitas siswa. Aktivitas siswa yang paling dominan adalah ketika siswa melakukan percobaan, pengamatan seperti petunjuk pada LKS. Baru setelah itu disusul dengan aktivitas mengerjakan LKS dan mendiskusikan tugas. Model pembelajaran inkuiri sebagai penganut pendekatan konstruktivis salah satunya adalah dengan menerapkan pembelajaran kooperatif secara luas, berdasarkan teori Piaget dan Vygotsky bahwa siswa akan lebih mudah untuk menemukan dan memahami konsep-konsep yang sulit jika mereka saling mendiskusikan masalah tersebut dengan temannya.

Siswa dengan rutin bekerja dalam kelompok untuk saling membantu memecahkan masalah-masalah yang kompleks (Nur, 2011). Meninjau proses ini sangatlah penting untuk PBM siswa mengingat banyaknya tugas dalam LKS yang perlu untuk didiskusikan siswa terutama ketika harus membuat analisis data yang sangat memerlukan pemikiran yang sangat teliti dari siswa. Baru setelah itu disusul dengan aktivitas mendengarkan penjelasan/bimbingan guru, mengkomunikasikan informasi, meliputi: menyumbang ide/pendapat, bertanya, dan presentasi, bertanya pada teman dan pada guru, mencatat, membaca Buku Ajar Siswa (mencari informasi tentang materi) dan yang rendah tingkat aktivitasnya adalah mengerjakan sesuatu yang tidak relevan, untuk aspek mengganggu teman, 
melamun, dan mencari perhatian. Hal ini terjadi karena siswa sudah disibukkan dengan banyak tugas sehingga aktivitas yang tidak relevan akan berkurang.

Berdasarkan hasil reliabilitas secara keseluruhan adalah 99,75\%. Berarti pada instrumen pengamatan aktivitas siswa melebihi dari $75 \%$ sehingga instrumen ini dikatagorikan reliabel. Hal ini sesuai dengan pendapat Borich (1994) dalam Ibrahim (2005) instrumen dikatakan reliabel dijadikan sebagai hasil pengamatan jika hasil reliabilitasnya melebihi 75\%, sehingga kesimpulannya adalah hasil data penelitian ini layak digunakan sebagai data penelitian.

Sedangkan aspek membaca, mengerjakan LKS dan mendiskusikan tugas, mengkomunikasikan informasi meliputi menyumbang ide/pendapat, bertanya, grafiknya mengalami kenaikan dari pertemuan 1 sampai pertemuan keempat. Hal ini terjadi karena pada saat membaca siswa memperoleh kedalaman pemahaman dan perspektif pribadi melalui berbagai sumber informasi, bukan bersumber dari guru saja, melainkan dapat berasal dari teman, BAS, maupun LKS. Saat mendiskusikan LKS siswa berkesempatan untuk berlatih kemampuan berargumentasi dan berbicara serta sebagai sarana untuk mengevaluasi konsep-konsep baru yang diperolehnya dari hasil kegiatan pembelajaran. Pada saat melakukan percobaan secara langsung siswa bertindak sebagai prakarsa dalam pencarian masalah, sebagai pelaku aktif dalam belajar melakukan penelitian, sebagai penjelajah dalam masalah metode pemecahan, dan sebagai penemu dalam pemecahan masalah, sehingga siswa akan mengurangi pencatatan terhadap materi.

Siswa dalam melakukan kegiatan percobaan ini semakin lihai dari tiap pertemuannya karena siswa sudah banyak memahami prosedur kerjanya sehingga waktu yang diperlukan untuk melakukan kegiatan ini hanya berkisar 15-20 menit saja. Pentingnya membaca BAS di rumah sangat membantu siswa dalam proses PBM, sehingga kegiatan siswa untuk mencatat akan semakin berkurang. Grafik untuk aktivitas siswa mendengarkan penjelasan/bimbingan guru, bertanya pada teman dan pada guru, perilaku yang tidak relevan meliputi: percakapan yang tidak relevan, mengerjakan sesuatu yang tidak relevan mengalami naik turun.

Minat siswa terhadap pembelajaran menurun disebabkan karena siswa merasa kesulitan dalam mengikuti pelajaran dan merasa belum memahami penjelasan yang diberikan oleh guru sehingga mereka bertanya langsung pada guru atau pada temannya. Selain itu juga masih ada siswa yang kurang menyadari akan pentingnya mendengarkan penjelasan guru yang menyebabkan siswa cenderung untuk ngobrol dengan temannya sehingga suasana kelas menjadi kurang kondusif. Keberadaan siswa seperti inilah yang harus banyak mendapatkan arahan dan bimbingan dari guru di dalam PBM. Padahal seharusnya siswa mendengarkan penjelasan dari guru agar proses PBM menjadi lancar. Mendengarkan penjelasan guru sangat penting untuk memperoleh informasi dan memperlancar penelitian karena guru bertindak sebagai fasilitator, teman diskusi, menciptakan suasana bebas berfikir sehingga siswa bebas bereksplorasi dalam penemuan dan pemecahan masalah, dan sebagai pembimbing dalam penelitian (Dimyati, dkk., 2009). Minat siswa terhadap pembelajaran menaik setelah siswa memahami penjelasan guru, sehingga siswa cenderung tidak banyak bertanya atau ada yang bertanya tetapi seperlunya saja, dan memungkinkan kondisi kelas lebih kondusif.

\section{Kendala-Kendala Selama Proses Penelitian}

Kendala yang dihadapi peneliti selama penelitian antara lain adalah:

a. Pada saat proses Kegiatan Belajar Mengajar (KBM) memerlukan waktu yang lama, karena dalam belajar siswa memerlukan banyak penyesuaian belajar, oleh karena itu memerlukan waktu yang lama pada pertemuan 1 sampai pertemuan 3 yang dapat dibuat perinciannya sebagai berikut: pertemuan 1 memerlukan waktu 115 menit, pertemuan 2 memerlukan waktu 105 menit, dan pertemuan 3 memerlukan waktu 95 menit, sedangkan pada pertemuan 4 menepati waktu yang ditetapkan, yaitu 90 menit. Proses belajar dengan model pembelajaran ini siswa sangat memerlukan bimbingan dan arahan dari guru sehingga guru dengan bertahap membimbing siswa hingga siswa mampu menerima apa yang disampaikan oleh peneliti.

b. Ketidak hati-hatian siswa dalam melakukan praktek sehingga mengakibatkan alat rusak atau pecah. Usaha yang dilakukan peneliti menghadapi kendala ini adalah meminta siswa agar lebih hatihati lagi di dalam menggunakan alat praktikum karena banyak alat yang digunakan dalam penelitian ini terbuat dari kaca.

c. Pada saat praktikum ada anak yang kurang aktif mengikuti, hal ini disebabkan karena kurangnya kesadaran mereka untuk membangun kebersamaan dan kekompakan dalam satu tim. baik dapat menghambat pengerjaan tugas yang diberikan oleh peneliti. Cara mengatasi masalah yang peneliti alami ini menyadarkan kembali ke siswa akan pentingnya kekompakkan dalam satu tim kerja, saling bekerjasama, tanggungjawab dan saling menghormati pendapat anggota satu tim. 


\section{Keefektifan Perangkat Pembelajaran}

1. Respon Siswa

Hasil respon siswa menunjukkan bahwa sebagian besar siswa memberikan respon positif terhadap pembelajaran model inkuiri yang diintegrasikan dengan strategi peta konsep. Besar respon positif siswa sebesar $87,30 \% \%$ dan hanya $12,70 \%$ yang merespon negatif. Berdasarkan 10 aspek yang terdapat pada Lembar respon siswa terhadap pembelajaran menunjukkan bahwa ketertarikan siswa tentang komponen yang mendukung pembelajaran menggunakan model inkuiri yang diintegrasikan dengan peta konsep dapat diterima siswa dan hal ini berpengaruh pada kondisi belajar yang diikuti siswa selama belajar di kelas di mana siswa terlihat secara aktif dan berusaha mengikuti setiap tahapan pembelajaran dengan baik, karena model pembelajaran yang digunakan untuk mengajar adalah sangat relevan, bervariasi dan sesuai dengan karakteristik materi yang akan dibelajarkan.

Semakin banyak variasi yang digunakan dan sesuai dengan karakteristik pembelajaran, sehingga semakin menimbulkan ketertarikan siswa dalam mengikuti pembelajaran serta siswa mau aktif dan kreatif dalam pembelajaran yang tentunya dapat berpengaruh positif terhadap hasil belajar. Sementara itu Ari, dkk. (2012) menyatakan bahwa model pembelajaran inkuiri dapat disinergikan dengan teknik peta konsep karena struktur pengetahuan dianggap sebagai komponen penting untuk mahami ilmu pengetahuan dalam domain belajar.

Model pembelajaran inkuiri mendorong siswa menemukan pengetahuannya sendiri sedangkan teknik peta konsep mengikuti restrukturisasi dan evolusi struktur kognitif siswa, sedangkan hasil penemuan Sofiana, dkk. (2012), menyatakan bahwa alat evaluasi peta konsep dapat digunakan sebagai alat evaluasi untuk model pembelajaran inkuiri.

Hal ini relevan dengan pernyataan Edmondson (2000) dalam Lliwellin (2005) peta konsep telah banyak digunakan dalam menilai pengetahuan yang saat ini dimiliki dan mendokumentasikan perolehan dan perkembangan pengetahuan baru. Hal ini dapat dicapai cukup dengan meminta siswa membuat suatu peta konsep yang menuliskan pemahaman awalnya tentang topik tertentu sebelum memulai unit pelajaran. Saat siswa menyelesaikan peta konsep, guru dapat menentukan apa yang siswa ketahui tentang topik tersebut. Saat unit berjalan, siswa dapat kembali ke peta dan melakukan koreksi (dari kesalahpahaman sebelumnya) dan penambahan-penambahan, dengan mengutip informasi yang baru diperoleh dan menggunakan pensil warna atau pena yang berbeda untuk setiap revisi akan membuat kita mudah memvisualisasikan bagaimana pengetahuan dibangun dan dimodifikasi. Peta konsep kemudian berfungsi sebagai sarana untuk memulai diskusi tentang pengetahuan siswa sebelum dan sesudah KBM berlangsung.

\section{Ketuntasan Hasil Belajar Siswa}

Ketuntasan hasil belajar siswa yang diamati meliputi tes aspek pengetahuan dan tes aspek keterampilan proses sains. Adapun tes dilakukan sebanyak 2 kali, yaitu tes sebelum pembelajaran (pretest) dan tes setelah pembelajaran (posttest) dengan model pembelajaran inkuiri yang diintegrasikan dengan strategi peta konsep dengan materi pokok titrasi asam basa. Hasil desain perangkat dapat meningkatkan ketuntasan hasil belajar siswa, dibuktikan dengan $\mathrm{N}$ gain rata-rata untuk aspek pengetahuan dari kelas XI MIA-3 adalah 0.80 dengan kategori tinggi sedangkan untuk aspek keterampilan proses sains dari kelas XI MIA-3 $N$-gain rata-rata adalah 0,69 dengan kategori sedang (Hake, 1999).

Saat siswa diberi tugas untuk membaca materi sebelum belajar dan kemudian diminta membuat peta konsep ini memberikan petunjuk kepada guru tentang pemahaman pengetahuan awal siswa yang dapat digunakan guru memasuki tahap pembelajaran berikutnya, teori ini sejalan dengan pendapat Ausubel (Dahar, 1988) yang menyatakan bahwa faktor paling penting yang mempengaruhi pembelajaran adalah apa yang telah diketahui siswa (pengetahuan awal). Menurut teori Piaget (Arends, 2008) tentang teori akomodasinya menyatakan bahwa ketika pengetahuan lama untuk beradaptasi dengan lingkungan tidak berhasil maka siswa akan mengubah skema yang ada berdasarkan informasi baru atau pengalaman baru.

Pembelajaran dengan model inkuiri yang diintegrasikan dengan peta konsep oleh guru kepada siswa telah mampu memberikan dorongan, mengarahkan pertanyaan, isyarat dan petunjuk atau meminta mengklarifikasi pemikiran siswa tentang fenomena yang ada di LKS. Fenomena yang ada dalam LKS mampu mendorong siswa untuk melakukan kegiatan berfikir tentang membuat rumusan masalah dan rumusan hipotesis yang dilanjutkan rancangan percobaan, meliputi: membuat identifikasi variabel dan mendefinisikan variabel, menentukan alat dan bahan percobaan dan membuat prosedur kerja. Vygotsky berpendapat bahwa intelek akan berkembang ketika individu menghadapi pengalaman baru yang membingungkan serta ketika mereka berusaha mengatasi kesulitan yang ditimbulkan oleh pengalaman baru ini.

Hadirnya pengalaman baru ini ada kalanya siswa mengalami kesulitan. Adanya guru sebagai fasilitator, teman diskusi, pembimbing penelitian, dan pencipta suasana bebas berfikir, sehingga siswa berani 
berekplorasi dalam penemuan dan pemecahan masalah, dirasa sangat penting oleh siswa karena kesulitan yang dihadapinya akan terpecahkan. Kenyataannya tidak semua siswa punya keberanian untuk mengungkapkan kesulitannya kepada guru, sehingga kesulitannya ini akan ditanyakan ke teman sekelompoknya.

Fungsi pengumpulan informasi lewat teman, dan guru ini digunakan sebagai sarana untuk menghubungkan pengetahuan yang baru dengan pemahaman yang lama. Berdasarkan pendapat Arends (2008) menyatakan bahwa usaha untuk menemukan pemahaman ini individu menghubungkan pengetahuan baru dengan pengetahuan sebelumnya dan mengkonstruksikan makna baru.

Adanya sarana prasarana di sekolah seperti laboratorium kimia sangat membantu proses pembelajaran. Menurut Dewey bahwa untuk memecahkan permasalahan yang dipelajarinya selama belajar di sekolah siswa dapat memanfaatkan teori dan teknologi yang dipelajarinya selama belajar di sekolah melalui laboratorium sekolah.

Pada tahapan melakukan percobaan titrasi asam basa, siswa ikut terlibat langsung dalam proses belajar, sehingga siswa aktif disibukkan untuk menyelidiki kebenaran fenomena yang diajukan guru, dan secara tidak langsung siswa telah melakukan peranannya sebagai pengambil prakarsa dalam pencarian pemecahan masalah, sejalan pendapat Dimyati (2009) yang menyatakan bahwa siswa adalah sebagai pelaku aktif dalam belajar melakukan penelitian, penjelajah tentang masalah dan metode pemecahan dan penemu pemecahan masalah. Hal ini didukung pula oleh teori dari Bruner bahwa salah satu cara untuk memecahkan permasalahan sains adalah dengan cara melatihkan siswa melakukan penelitian yang menjadi prinsip pada pembelajaran dengan model inkuiri.

Materi titrasi asam basa merupakan salah satu materi yang termasuk dalam ilmu sains maka penerapan dengan penyelididkan melalui penentuan kadar zat asam ataupun basa sangat mungkin untuk diterapkan. Sedangkan salah satu cara untuk mengkonstruksi kognitif siswa dapat dilakukan dengan meminta siswa kembali membuat peta konsep di akhir pembelajaran, yaitu ketika siswa membuat analisis data percobaan. Hal itu merupakan salah satu kegunaan peta konsep menurut teori Ausubel adalah untuk menghubungkan pengetahuan baru dengan konsep-konsep relevan yang telah siswa miliki.

Berdasarkan pengalaman belajar inilah yang mampu memberikan dampak positif pada hasil belajar siswa yang lebih baik yang tercermin pada kemampuan menyelesaian soal tes aspek pengetahuan dan keterampilan proses sains yang diberikan pada siswa, di mana sebanyak $89,47 \%$ telah mencapai ketuntasan individu dan 100\% telah mencapai ketuntasan klasikal yang dapat diamati pada Tabel 6 untuk aspek pengetahuan siswa, sedangkan pada tes keterampilan proses sains $86,84 \%$ siswa telah mencapai ketuntasan individu dan mencapai ketuntasan klasikal yang dapat diamati pada Tabel 7 untuk keterampilan proses sains.

Secara keseluruhan dari 38 siswa yang mengikuti tes aspek pengetahuan dan tes keterampilan proses sains ada 34 siswa mendapatkan nilai nilai $>3,00$, dan 4 siswa mendapat nilai $<3,00$ pada aspek pengetahuan. 33 siswa mendapatkan nilai $>3,00$, dan 5 siswa memperoleh nilai $<3,00$ untuk tes keterampilan proses sains. Nilai ini menunjukkan bahwa siswa yang dinyatakan tuntas secara individu ada 34 siswa, sedangkan 4 siswa dianggap tidak tuntas pada aspek pengetahuan, sedangkan 33 siswa dianggap tuntas secara individu, sedangkan 5 siswa dianggap tidak tuntas untuk tes keterampilan proses sains.

Keberhasilan siswa dalam belajar ini dipengaruhi oleh cara mengajar guru dan proses pemberian bimbingan guru pada saat pembelajaran yang berpengaruh pada minat siswa terhadap pembelajaran. Siswa yang tuntas dalam pembelajaran materi pokok titrasi asam basa ini cenderung merasa jelas dengan cara mengajar guru dan dalam menerima bimbingan guru sehingga punya kecenderungan untuk memiliki minat dalam belajar pada materi pokok titrasi asam basa, sedangkan siswa yang nilainya tidak tuntas cenderung merasa tidak jelas atas cara mengajar dan bimbingan guru, sehingga siswa cenderung kurang berminat dalam mengikuti pelajaran pada pokok materi titrasi asam basa.

Hal ini dapat diamati pada hasil respon siswa pada Tabel 5 yang memperlihatkan respon siswa terhadap cara mengajar guru bahwa 92,1\% siswa merespon positif dan 7,9\% siswa merespon negatif. Guru dalam memberikan bimbingan saat mengerjakan LKS memperoleh respon $97,3 \%$ siswa merespon positif dan $2,6 \%$ siswa merespon negatif, sedangkan minat siswa terhadap pembelajaran $92,1 \%$ siswa merespon positif dan 7,9\% siswa merespon negatif.

Selain dapat dilihat dari cara mengajar dan bimbingan yang dilakukan guru. Proses pembelajaran menggunakan model inkuiri yang diintegrasikan dengan peta konsep juga berpengaruh pada minat belajar siswa, keberhasilan belajar siswa dapat dilihat dari aktivitas yang dilakukan siswa.

Siswa yang berhasil dalam belajar cenderung melakukan aktivitas relevan seperti yang diharapkan oleh guru seperti membaca buku ajar, melakukan percobaan sesuai dengan petunjuk LKS, mengerjakan LKS dan melakukan diskusi dengan teman satu team, membuat catatan pada materi yang dianggap penting, mendengarkan penjelasan dan bimbingan guru, 
bertanya pada teman dan guru, mengkomunikasikan informasi meliputi menyumbangkan ide/pendapat, bertanya dan mengurangi perilaku yang tidak relevan, sedangkan siswa yang tidak tuntas cenderung lebih banyak melakukan perilaku yang tidak relevan seperti: ngobrol dengan teman, dan kurang berperan aktif dalam proses KBM (diam) .

Penerapan model pembelajaran inkuiri yang diintegrasikan dengan strategi peta konsep punya pengaruh terhadap keberhasilan hasil belajar siswa. Hal ini terlihat dari $N$ - Gain score pada hasil belajar siswa SMAN 1 Sangatta Uatara, yaitu ada siswa yang peningkatan hasil belajarnya tinggi dan ada juga peningkatan hasil belajarnya sedang. Tinggi dan sedangnya peningkatan hasil belajar yang diperoleh siswa bergantung pada kemampuan siswa dalam mengikuti kegiatan selama proses pembelajaran baik itu melalui proses belajar mandiri maupun belajar kelompok yang termuat dalam model pembelajaran inkuiri yang diintegrasikan dengan strategi peta konsep.

Belajar mandiri difungsikan agar siswa nantinya mampu memfilter proses asimilasi ide-ide baru di struktur kognitif siswa asalkan sumber informasinya tidak menimbulkan konsep yang salah Piaget (Dahar, 1998), dalam penelitian yang dilakukan oleh Yunianti, dkk. (2012), menemukan bahwa ada pengaruh kemampuan pemahaman membaca terhadap prestasi belajar siswa, kemudian menyuruh siswa menyusun kembali konsep-konsep pengetahuan yang diperolehnya dalam bentuk peta konsep. karena sesuai pendapat Ausubel belajar akan bermakna, jika siswa mampu mengaitkan konsep yang baru dengan struktur kognitif siswa, dan cara yang dapat dilakukan menurut Novak \& Gowin (1985) dalam Dahar (1988) adalah dengan pertolongan peta konsep.

Kondisi siswa punya keterbatasan untuk berfikir tentang hal-hal yang rumit, sehingga untuk membantu keberhasilannya dalam belajar ini dapat dilakukan dengan berinteraksi dengan teman sebaya yang kompeten atau orang dewasa yang kompeten sesuai teori Vygotsky (Arends, 2008). Proses ini dapat dilakukan melalui belajar kelompok, ketika guru membentuk kelompok belajar di dalam kelas untuk melakukan kegiatan diskusi sekaligus untuk menyelesaikan permasalahan berupa merumuskan masalah, merumuskan hipotesis, menyusun variabel operasional, mendefinisikan variabel operasional, merancang percobaan, melakukan penelitian, mengorganisasi data, menganalisis data dan membuat kesimpulan dari fenomena yang disajikan di LKS, maka akan terjadi interaksi siswa dengan teman sebayanya atau siswa dengan guru sebagai pembimbing/fasilisator dalam proses pembelajaran di kelas dan siswa akan memperoleh pengalaman baru sehingga mampu mengubah skema yang ada berdasarkan informasi baru yang diperoleh selama belajar sesuai teori Piaget (Arends, 2008).

Rasa ingin tahu yang besar akan pentingnya pengetahuan dapat dilakukan ketika siswa mampu menggunakan seluruh inderanya untuk berinteraksi dengan benda (Piaget, dalam Arends, 2008). Hal ini menyebabkan siswa akan aktif mengikuti setiap perkembangan pembelajaran yang dialaminya sehingga proses pengetahuan siswa berlangsung.

Tentunya dalam belajar dengan menggunakan model inkuiri yang diintegrasikan dengan strategi peta konsep, mampu membentuk pengalaman baru siswa dalam mengingat (Dewey dalam Arends, 2008). Siswa mampu terdorong untuk memecahkan permasalahan yang dihadapinya melalui pengamatan langsung di laboratorium sebagai tempat belajarnya yang baru, sangat memerlukan adanya kerjasama, ketelitian, dan tanggungjawab yang besar dari setiap kelompok sehingga akan dihasilkan suatu konsep yang benar sesuai yang diharapkan oleh guru.

Hal ini dapat dilatihkan secara bertahap pemecahan masalahnya lewat inkuiri (Bruner, dalam Arends, 2008), berdasarkan penemuan Praptiwi (2012) bahwa penguasaan konsep bisa terjadi melalui pembelajaran inkuiri dikarenakan pengetahuan penyelidikan akan lebih mudah diingat.

Peningkatan penguasaan konsep dapat terjadi karena pembelajaran berbasis inkuiri dapat membuat siswa berfikir bagi dirinya sendiri, berperan serta dalam proses perolehan pengetahuan dan dalam pencarian konsep yang dipelajari siswa sehingga retensi terhadap konsep yang didapatkan akan lebih lama dibandingkan hanya mendapatkan konsep tersebut dari penjelasan guru.

Besar peningkatan keberhasilan hasil nilai aspek pengetahuan dan keterampilan proses sains dapat dihitung menggunakan perhitungan $N$-gain, Aspek pengetahuan Tabel 5 menunjukkan bahwa $N$-gain sedang dicapai ada 6 siswa dan nilai yang diperoleh berkisar 0,45 - 0,69 dan $N$-gian tinggi ada 32 siswa dan nilai yang diperoleh berkisar $0,75-0,98$, sedangkan untuk keterampilan proses sains (Tabel 6) menunjukkan bahwa nilai $N$-gain sedang dicapai ada 22 siswa dan nilai yang diperoleh berkisar $0,54-0,69$ dan $N$-gian tinggi ada 16 siswa dan nilai yang diperoleh berkisar 0,70 - 0,87. Berdasarkan hasil ini berarti pada aspek pengetahuan ada 32 siswa yang sangat baik dalam memahami soal tes dan ada 6 siswa yang cukup baik dalam memahami soal tes aspek pengetahuan, sedangkan pada tes keterampilan proses sains ada 16 siswa sangat baik dalam memahami soal tes dan ada 22 siswa cukup memahami soal tes yang diujikan pada uji coba 2 . 


\section{PENUTUP \\ Simpulan}

Berdasarkan analisis, pembahasan dan temuan hasil penelitian dapat dapat dibuat kesimpulan, bahwa perangkat pembelajaran kimia materi pokok titrasi asam basa menggunakan model inkuiri yang diintegrasikan dengan strategi peta adalah valid, praktis dan efektif digunakan untuk meningkatkan hasil belajar siswa.

\section{Saran}

Mengingat penelitian ini masih banyak kekurangannya, maka peneliti memberikan beberapa saran dari hasil penelitian yang dilakukan adalah sebagai berikut:

1. Sebelum proses KBM berlangsung agar penelitian lebih efisien dan menghasilkan hasil yang maksimal siswa perlu dilatih terlebih dahulu tentang penggunaan alat dan bahan titrasi, tahapan sintaks inkuiri, dan cara pembuatan peta konsep.

2. Sebelum proses KBM berlangsung siswa perlu diingatkan akan pentingnya tanggungjawab merawat alat dan bahan titrasi.

3. Sebelum proses KBM berlangsung siswa perlu diingatkan akan pentingnya partisipasi aktifnya di dalam mengikuti proses KBM terutama dalam melakukan praktikum titrasi asam basa.

\section{DAFTAR PUSTAKA}

Adi, M. R., Sudiana, I. W., Resana, I. Dw. Pt. (2012). Pengaruh Model Pembelajaran Inkuiri Terbimbing Berbantukan Teknik Peta Konsep Terhadap Pemahaman Konsep IPA Siswa Kelas $V$ SD Desa Kali Asem. Singaraja: PPs. PGSD. Universitas Ganesha. Tersedia di ejournal.undiksha.ac.id/

index.php/JJPGSD/article/viewFile/3058 /2532.

Diakses tanggal 15 April 2014.

Arends, R.I. (2008). Belajar untuk Mengajar. Penerjemah oleh Soetjipto, H.P \& Soetjipto, S.M. Yogyakarta: PT. Pustaka Pelajar.

Ari, N. M., Dantes, N, dan Tastra, I. D. K. (2012). Pengaruh Model Pembelajaran Inkuiri Terbimbing Berbantuan Peta Konsep terhadap Hasil Belajar IPA Kelas $V$. Singaraja: PPs. PGSD. Universitas Ganesha. Tersedia di ejournal. undiksha. ac.id/index.php/ JJPGSD/article/ viewFile/3058/ 2532. Diakses tanggal $20 \mathrm{Mei} 2014$.

Ariadi, B.Y. (2010). Metode Pembelajaran Inkuiri. Tersedia di http://bambangariadi.

Wordpress.com/2010/02/12/metode

pembelajaran inkuiri/. Diakses tanggal 20 November 2014.

BNSP. (2006). Panduan Penyusunan KTSP. Jakarta. Depdiknas.
BSNP. (2010). Paradigma Pendidikan Nasional Abad XXI. Badan Standar Nasional Pendidikan Versi 1. Jakarta.

Dahar, R.W. (1988). Teori- Teori Belajar. Jakarta: Erlangga.

Dimyati \& Mudjiono. (2009). Belajar dan Pembelajaran. Jakarta: Rineka Cipta.

Emzir. (2007). Metodologi Penelitian Pendidikan Kualitatif \& Kuantitatif. Jakarta: PT. Rajagrafindo Persada.

Fleischman, H. L., Pelezar, M.P., and Shelley, B.F. (2010). Highlight From PISA 2009. Performance of U.S. 15-Years-Old Student in Reading Mathematics, and Science Literacy in an International Context. NSES. U. S. Departement of Education.

Hake, R.R. (1999). Analyzing Change/Gain Score. Indiana University. Terdapat di http://www.physics.indiana.edu/ $\sim_{\text {sdi/Analysing }}$ Change-Gain.pdf. Diakses tanggal 25 Maret 2014.

Ibrahim, M. (2005). Asesmen Berkelanjutan. Konsep Dasar, Tahapan Pengembangan dan Contoh. Surabaya: Unesa University Press.

Ibrahim, M. (2005). Asesmen Berkelanjutan. Konsep Dasar, Tahapan Pengembangan dan Contoh. Surabaya: Unesa University Press.

Joyce, B \& Weil. (2000). Models of Teaching. Sixtth Edition. USA:Allyn and Bacon Publishing Company.

Llewellyn. (2005). Teaching High School Science Through Inquiry. California: ASTApress.

Lynch, P.P \& Water, M. (1990). Experiment of New Chemestry Student Concerning Chemistry Courses. Chemistry in Australia. 47, 238-242.

Muin, F. (2011).Pendidikan Karakter Kontruksi dan Praktik Urgensi Pendidikan Progresif dan Revitalisasi Peran Guru dan Orang Tua. Jakarta: Pustaka Rudaskarya.

Nakhleh, MB. (1992). Why Some Student Don't Learn. Chemical Misconceptions. Journal of Chemistry Education. 69, 196-199.

Nieveen, N. (1999). Prototyping to reach Product Quality. University of Twente.

Nur, M., Wikandari, P.M. (2008). Pengajaran Berpusat pada Siswa dan Pendekatan Konstruktivisme dalam Pengajaran. (Edisi 5). Surabaya: Penerbit Pusat Sains dan Matematika Sekolah. Unesa University Press. 
Nur, M. (2011). Strategi-Strategi Belajar. Surabaya:Unesa University Press.

Poerwati, L.I. \& Amri, S. (2013). Panduan memahami kurikulum 2013 Sebuah Inovasi Penunjang Masa Depan. Jakarta: Prestasi Pustaka Publiser.

Praptiwi, L., Sarwi, dan Handayani, L. (2012). Efektivitas Model Pembelajaran Eksperimen Inkuiri Terbimbing Berbantuan My Own Dictionary untuk Meningkatkan Penguasaan Konsep dan Unjuk Kerja Siswa SMP RSBI. Unnes Science Education Journal. 1 (2), 86 95.

Rahayu, T., \& Yonata, B. (2013). Kemampuan Kognitif Siswa Kelas XI IPA 1 SMA Negeri 18 Surabaya pada tingkat Analisis, Evaluasi, dan Kreasi pada Materi Titrasi Asam Basa dengan penerapan Model Pembelajaran Inkuiri. Unesa Journal of Chemical Education. 2 (2), 12-16.

Saptorini. 2008. Pengembangan Model Pembelajaran Berbasis Ikuiri Sebagai Upaya Peningkatan Kemampuan Inkuiri Guru Kimia Kabupaten Demak. Demak. Jurnal Unnes. Tersedia di @.id/njy/index.php/rekayasa/.../291 . Diakses tanggal 6 Maret 2014.

Sidi, I.D. (2000). Pendidikan IPA di Lingkungan Pendidikan Dasar dan Menengah. Bandung. ITB.

Silitonga, P.M. (2004). Analisis dan Peningkatan Kemampuan Guru dalam Menyusun Peta Konsep sebagai Media dan Alat Evaluasi dalam Pengajaran Kimia SMU. Jurnal Pendidikan Matematika dan sains. 1 (3), 93 - 96.Tersedia di http:

//www.geocities.ws/J_sains/vol1_No3.html.

Diakses tanggal 3 Maret 2015.

Slavin, R. E. (2011). Psikologi Pendidikan Teori dan Praktik. Jilid 1. Penerjemah samosir, M. Jakarta: Indeks.

Sofiana, N., Made, N.DP., dan Nugroho, S.E. (2012). Pengembangan Evaluasi Peta Konsep dalam Pembelajaran Inkuiri pada Pokok Bahasan Kalor. Unnes Physics Education Journal. 1 (1), $38 \quad-\quad 43 . \quad$ Tersedia di http://journal.unnes.ac.id/sju/ index. Php/upej. Diakses tanggal 20 Februari 2015.

Wahyudi, A. (2013). Pengaruh Peta Konsep dalam Pembelajaran Inkuiri Terbimbing Ditinjau dari Kemampuan Bernalar siswa Kelas XI. Malang: PPS. Universitas Negeri Malang. Jurnal Pendidikan. 1 (3), 237-245.

Yunianti, E. D., Sunarno, W., dan Haryono. (2012). Pembelajaran Kimia Menggunakan Inkuiri Terbimbing dengan Menggunakan Modul E- Learning Ditinjau dari Kemampuan Pemahaman membaca dan Kemampuan Berfikir Abstrak. Jurnal pasca Uns. 1 (2), 112-120. 